\title{
Quantitative Structure-Property Relationship Analysis Against Critical Micelle Concentration of Sulfonate-Based Surfactant Based on Semiempirical Zindo/1 Calculation
}

\author{
Ponco Iswanto 1*, Eva Vaulina Yulistia Delsy', Ely Setiawan', \\ Fiandy Aminullah Putra'
}

'Physical Chemistry Laboratory, Chemistry Department, Faculty of Mathematics and Natural Sciences, Universitas Jenderal Soedirman, JI. Dr. Suparno, Karangwangkal, Purwokerto 53123, Indonesia

*Corresponding author email: poncoiswanto@gmail.com

Received December 16, 2018; Accepted August 21, 2019; Available online November 30, 2019

\begin{abstract}
Development of anionic surfactant compound is very important because the anionic surfactant class is widely used in people's lives. For instance, anionic surfactants are used as food additives and detergents. The novel compound of sulfonate-based surfactant or proposed compound has predicted the Critical Micelle Concentration (CMC) value of experiment. Quantitative Structure-Property Relationship (QSPR) analysis based on semiempirical ZINDO/1 calculation was conducted to obtain QSPR equation. Theoretical predictors or independent variable which have an influence on the value of CMC are used to construct QSPR equation. The theoretical predictors are classified into predictor of electronic properties, solubility and steric. A total of 108 experimental CMC belongs to sulfonate-based surfactant are calculated their theoretical predictors and analyzed by multiple linear regression. The QSPR equation which is obtained from this study contains the important theoretical predictors. They are solubility properties, molecular weight, molecular size and net charge of carbon atom in the polar part of sulfonate-based surfactant. This QSPR equation could be used to predict the CMC value of the novel sulfonate-based surfactant.
\end{abstract}

Keywords: surfactant, sulfonate, QSPR, ZINDO/1

\section{INTRODUCTION}

Surfactant or surface active agent is an important substance. Surfactant has hydrophilic and hydrophobic part. So, it is active on the surface of two immiscible materials and can make the two immiscible materials become one phase (Haftka, 2016). Surfactant also can decrease the surface tension. Surfactant is divided into 4 types such as cationic, anionic, non-ionic and amphoteric surfactant. The surfactant that has a lot of application is anionic surfactant. It can be used as food additive, emulsifier agent at drug industry and also detergent (Paulo, 2017). Since the anionic surfactant has a lot of applications, it needs the development to produce qualified anionic surfactant. A good surfactant has low value of Critical Micelle Concentration (CMC). The CMC is the value of surfactant concentration where the surfactant molecules start to turn into a micelle. A micelle is an aggregation structure of some surfactant molecules in liquid system.

The CMC value becomes important data. The CMC value determination is not easy experimentally (Zhu, 2014). It could be conducted by plotting a graph of a suitable physical property as a function of surfactant concentration. Plotting a graph of a suitable physical property as a function of surfactant concentration. An abrupt change of slope marks the CMC. The determination of CMC value is difficult, since the change in slope occurs over a more or less narrow range of concentrations and also need a lot of surfactant quantity.

Computational chemistry is proven as useful technique to predict the activity (Iswanto, 2011), synthesis the novel molecule such as anticancer molecule and even the melting point of carbocyclic nitro aromatic compounds (Elidrissi, 2017). This computational chemistry approach is quantitative structure-property relationship (QSPR) analysis (Huibers, 1999). This work is conducted in order to obtain the QSPR equation based on semi empirical ZINDO/1 calculation. This method is the most appropriate method for energy and determining structures of molecules with first or second row metal transition. The experimental data which are used to obtain the QSPR equation are CMC value of sulfonate-based surfactant. The QSPR equation or mathematical equation could be applied to predict the CMC value of novel sulfonate-based surfactant.

\section{EXPERIMENTAL SECTION \\ Materials}

The experimental Critical Micelle Concentration (CMC) data and molecular formula of 108 anionic 
sulfonate-based surfactants (Table 1) (Huibers, 1999)

\section{Instrumentation}

The computational chemistry software for calculating the geometry optimization and theoretical predictor or independe variable of sulfonate-based Surfactant was HypercheRelease 8.0 (Hypercube, 2007). Multiple Linear Regresion (MLR) used as statistical analysis to obtain the Quantitative Structure-Property Relationship (QSPR) equation.

Table 1. Sulfonate surfactants and their experimental CMC value (Log CMC form) (Huibers, 1999)

\begin{tabular}{|c|c|c|c|c|c|}
\hline Compound & Log CMC & Compound & $\log C M C$ & Compound & $\log C M C$ \\
\hline $\mathrm{C}_{10} \mathrm{PhSO}_{3} \mathrm{Na}$ & -2.509 & $\mathrm{C}_{7} \mathrm{C}\left(\mathrm{C}_{7}\right) \mathrm{SO}_{3} \mathrm{Na}$ & -2.144 & $\mathrm{C}_{15} \mathrm{C}(\mathrm{OH}) \mathrm{C}_{2} \mathrm{SO}_{3} \mathrm{Na}$ & -3.420 \\
\hline $\mathrm{C}_{12} \mathrm{PhSO}_{3} \mathrm{Na}$ & -2.921 & $\mathrm{C}_{7} \mathrm{PhSO}_{3} \mathrm{Na}$ & -1.582 & $\mathrm{C}_{10} \mathrm{EOSO}_{3} \mathrm{Na}$ & -1.787 \\
\hline $\mathrm{C}_{8} \mathrm{C}\left(\mathrm{C}_{2}\right) \mathrm{PhSO}_{3} \mathrm{Na}$ & -2.500 & $\mathrm{C}_{8} \mathrm{PhSO}_{3} \mathrm{Na}$ & -1.907 & $\mathrm{C}_{10} \mathrm{C}(\mathrm{C}(\mathrm{OH})) \mathrm{SO}_{3} \mathrm{Na}$ & -1.787 \\
\hline $\mathrm{C}_{7} \mathrm{C}\left(\mathrm{C}_{3}\right) \mathrm{PhSO}_{3} \mathrm{Na}$ & -2.400 & $\mathrm{C}_{6} \mathrm{C}\left(\mathrm{C}_{2}\right) \mathrm{PhSO}_{3} \mathrm{Na}$ & -1.967 & $\mathrm{C}_{12} \mathrm{C}(\mathrm{C}(\mathrm{OH})) \mathrm{SO}_{3} \mathrm{Na}$ & -2.432 \\
\hline $\mathrm{C}_{6} \mathrm{C}\left(\mathrm{C}_{4}\right) \mathrm{PhSO}_{3} \mathrm{Na}$ & -2.300 & $\mathrm{C}_{8} \mathrm{C}(\mathrm{C}) \mathrm{PhSO}_{3} \mathrm{Na}$ & -2.303 & $\mathrm{C}_{6} \mathrm{CO}_{2} \mathrm{CSO}_{3} \mathrm{Na}$ & -0.733 \\
\hline $\mathrm{C}_{5} \mathrm{C}\left(\mathrm{C}_{5}\right) \mathrm{PhSO}_{3} \mathrm{Na}$ & -2.250 & $\mathrm{C}_{7} \mathrm{C}\left(\mathrm{C}_{2}\right) \mathrm{PhSO}_{3} \mathrm{Na}$ & -2.200 & $\mathrm{C}_{8} \mathrm{CO}_{2} \mathrm{CSO}_{3} \mathrm{Na}$ & -1.144 \\
\hline $\mathrm{C}_{7} \mathrm{C}\left(\mathrm{C}_{4}\right) \mathrm{PhSO}_{3} \mathrm{Na}$ & -2.570 & $\mathrm{C}_{5} \mathrm{C}\left(\mathrm{C}_{4}\right) \mathrm{PhSO}_{3} \mathrm{Na}$ & -2.047 & $\mathrm{C}_{10} \mathrm{CO}_{2} \mathrm{CSO}_{3} \mathrm{Na}$ & -1.621 \\
\hline $\mathrm{C}_{10} \mathrm{C}\left(\mathrm{C}_{2}\right) \mathrm{PhSO}_{3} \mathrm{Na}$ & -3.000 & $\mathrm{C}_{9} \mathrm{C}(\mathrm{C}) \mathrm{PhSO}_{3} \mathrm{Na}$ & -2.721 & $\mathrm{C}_{14} \mathrm{CO}_{2} \mathrm{C}_{2} \mathrm{SO}_{3} \mathrm{Na}$ & -3.046 \\
\hline $\mathrm{C}_{9} \mathrm{C}\left(\mathrm{C}_{3}\right) \mathrm{PhSO}_{3} \mathrm{Na}$ & -2.900 & $\mathrm{C}_{10} \mathrm{C}(\mathrm{C}) \mathrm{PhSO}_{3} \mathrm{Na}$ & -2.692 & $\mathrm{C}_{10} \mathrm{C}\left(\mathrm{CO}_{2} \mathrm{C}\right) \mathrm{SO}_{3} \mathrm{Na}$ & -1.986 \\
\hline $\mathrm{C}_{8} \mathrm{C}\left(\mathrm{C}_{4}\right) \mathrm{PhSO}_{3} \mathrm{Na}$ & -2.780 & $\mathrm{C}_{9} \mathrm{C}\left(\mathrm{C}_{2}\right) \mathrm{PhSO}_{3} \mathrm{Na}$ & -2.606 & $\mathrm{C}_{12} \mathrm{C}\left(\mathrm{CO}_{2} \mathrm{C}\right) \mathrm{SO}_{3} \mathrm{Na}$ & -2.583 \\
\hline $\mathrm{C}_{7} \mathrm{C}\left(\mathrm{C}_{5}\right) \mathrm{PhSO}_{3} \mathrm{Na}$ & -2.700 & $\mathrm{C}_{8} \mathrm{C}\left(\mathrm{C}_{3}\right) \mathrm{PhSO}_{3} \mathrm{Na}$ & -2.721 & $\mathrm{C}_{14} \mathrm{C}\left(\mathrm{CO}_{2} \mathrm{C}\right) \mathrm{SO}_{3} \mathrm{Na}$ & -3.398 \\
\hline $\mathrm{C}_{6} \mathrm{C}\left(\mathrm{C}_{6}\right) \mathrm{PhSO}_{3} \mathrm{Na}$ & -2.600 & $\mathrm{C}_{6} \mathrm{C}\left(\mathrm{C}_{5}\right) \mathrm{PhSO} 3 \mathrm{Na}$ & -2.585 & $\mathrm{C}_{14} \mathrm{C}\left(\mathrm{CO}_{2} \mathrm{C}_{2}\right) \mathrm{SO}_{3} \mathrm{Na}$ & -3.509 \\
\hline $\mathrm{C}_{12} \mathrm{C}(\mathrm{C}) \mathrm{PhSO}_{3} \mathrm{Na}$ & -3.390 & $\mathrm{C}_{11} \mathrm{C}(\mathrm{C}) \mathrm{PhSO}_{3} \mathrm{Na}$ & -3.208 & $\mathrm{C}_{14} \mathrm{C}\left(\mathrm{CO}_{2} \mathrm{C}_{3}\right) \mathrm{SO}_{3} \mathrm{Na}$ & -3.964 \\
\hline $\mathrm{C}_{11} \mathrm{C}\left(\mathrm{C}_{2}\right) \mathrm{PhSO}_{3} \mathrm{Na}$ & -3.280 & $\mathrm{C}_{13} \mathrm{C}(\mathrm{C}) \mathrm{PhSO}_{3} \mathrm{Na}$ & -3.577 & $\mathrm{C}_{16} \mathrm{C}\left(\mathrm{CO}_{2} \mathrm{C}\right) \mathrm{SO}_{3} \mathrm{Na}$ & -4.000 \\
\hline $\mathrm{C}_{10} \mathrm{C}\left(\mathrm{C}_{3}\right) \mathrm{PhSO}_{3} \mathrm{Na}$ & -3.150 & $\mathrm{C}_{9} \mathrm{C}(\mathrm{OH}) \mathrm{C}_{2} \mathrm{SO}_{3} \mathrm{Na}$ & -1.606 & $\mathrm{C}_{16} \mathrm{C}\left(\mathrm{CO}_{2} \mathrm{C}_{2}\right) \mathrm{SO}_{3} \mathrm{Na}$ & -4.106 \\
\hline $\mathrm{C}_{9} \mathrm{C}\left(\mathrm{C}_{4}\right) \mathrm{PhSO}_{3} \mathrm{Na}$ & -3.050 & $\mathrm{C}_{9} \mathrm{C}(\mathrm{OC}) \mathrm{C}_{2} \mathrm{SO}_{3} \mathrm{Na}$ & -2.118 & $\mathrm{C}_{16} \mathrm{C}\left(\mathrm{CO}_{2} \mathrm{C}_{3}\right) \mathrm{SO}_{3} \mathrm{Na}$ & -4.899 \\
\hline $\mathrm{C}_{8} \mathrm{C}\left(\mathrm{C}_{5}\right) \mathrm{PhSO}_{3} \mathrm{Na}$ & -2.900 & $\mathrm{C}_{9} \mathrm{C}\left(\mathrm{OC}_{2}\right) \mathrm{C}_{2} \mathrm{SO}_{3} \mathrm{Na}$ & -2.301 & $\mathrm{C}_{16} \mathrm{C}\left(\mathrm{CO}_{2} \mathrm{C}(\mathrm{C}) \mathrm{C}\right) \mathrm{SO}_{3} \mathrm{Na}$ & -4.569 \\
\hline $\mathrm{C}_{7} \mathrm{C}\left(\mathrm{C}_{6}\right) \mathrm{PhSO}_{3} \mathrm{Na}$ & -2.800 & $\mathrm{C}_{9} \mathrm{C}\left(\mathrm{OC}_{3}\right) \mathrm{C}_{2} \mathrm{SO}_{3} \mathrm{Na}$ & -2.420 & $\mathrm{C}_{4} \mathrm{C}\left(\mathrm{C}_{2}\right) \mathrm{CCO}_{2} \mathrm{CC}\left(\mathrm{SO}_{3} \mathrm{Na}\right) \mathrm{CO}_{2}$ & $2-2.566$ \\
\hline $\mathrm{C}_{8} \mathrm{CO}_{2} \mathrm{C}_{2} \mathrm{SO}_{3} \mathrm{Na}$ & -1.312 & $\mathrm{C}_{9} \mathrm{C}(\mathrm{OC}(\mathrm{C}) \mathrm{C}) \mathrm{C}_{2} \mathrm{SO}_{3} \mathrm{Na}$ & -2.458 & $\mathrm{C}_{4} \mathrm{CO}_{2} \mathrm{C}\left(\mathrm{SO}_{3} \mathrm{Na}\right) \mathrm{CCO}_{2} \mathrm{C}_{4}$ & -0.663 \\
\hline $\mathrm{C}_{10} \mathrm{CO}_{2} \mathrm{C}_{2} \mathrm{SO}_{3} \mathrm{Na}$ & -1.883 & $\mathrm{C}_{9} \mathrm{C}\left(\mathrm{OC}_{4}\right) \mathrm{C}_{2} \mathrm{SO}_{3} \mathrm{Na}$ & -2.817 & $\mathrm{C}_{5} \mathrm{CO}_{2} \mathrm{C}\left(\mathrm{SO}_{3} \mathrm{Na}\right) \mathrm{CCO}_{2} \mathrm{C}_{5}$ & -1.239 \\
\hline $\mathrm{C}_{12} \mathrm{CO}_{2} \mathrm{C}_{2} \mathrm{SO}_{3} \mathrm{Na}$ & -2.523 & $\mathrm{C}_{9} \mathrm{C}\left(\mathrm{OC}_{6}\right) \mathrm{C}_{2} \mathrm{SO}_{3} \mathrm{Na}$ & -3.185 & $\mathrm{C}_{6} \mathrm{CO}_{2} \mathrm{C}\left(\mathrm{SO}_{3} \mathrm{Na}\right) \mathrm{CCO}_{2} \mathrm{C}_{6}$ & -1.817 \\
\hline $\mathrm{C}_{6} \mathrm{SO}_{3} \mathrm{Na}$ & -0.496 & $\mathrm{C}_{9} \mathrm{C}\left(\mathrm{OC}_{8}\right) \mathrm{C}_{2} \mathrm{SO}_{3} \mathrm{Na}$ & -3.922 & $\mathrm{C}_{8} \mathrm{CO}_{2} \mathrm{C}\left(\mathrm{SO}_{3} \mathrm{Na}\right) \mathrm{CCO}_{2} \mathrm{C}_{8}$ & -3.131 \\
\hline $\mathrm{C}_{8} \mathrm{SO}_{3} \mathrm{Na}$ & -0.796 & $\mathrm{C}_{9} \mathrm{C}\left(\mathrm{OCC}\left(\mathrm{C}_{2}\right) \mathrm{C}_{4}\right) \mathrm{C}_{2} \mathrm{SO}_{3} \mathrm{Na}$ & a -3.501 & $\mathrm{C}_{5} \mathrm{PhePhSO}{ }_{3} \mathrm{Na}$ & -1.817 \\
\hline $\mathrm{C}_{10} \mathrm{SO}_{3} \mathrm{Na}$ & $-1,398$ & $\mathrm{C}_{9} \mathrm{C}(\mathrm{OPh}) \mathrm{C}_{2} \mathrm{SO}_{3} \mathrm{Na}$ & -2.708 & $\mathrm{C}_{8} \mathrm{PhePhSO}{ }_{3} \mathrm{Na}$ & -2.817 \\
\hline $\mathrm{C}_{12} \mathrm{SO}_{3} \mathrm{Na}$ & -1.959 & $\mathrm{C}_{9} \mathrm{C}(\mathrm{O}) \mathrm{C}_{2} \mathrm{SO}_{3} \mathrm{Na}$ & -1.541 & $\mathrm{C}_{10} \mathrm{PhePhSO}_{3} \mathrm{Na}$ & -3.445 \\
\hline $\mathrm{C}_{13} \mathrm{SO}_{3} \mathrm{Na}$ & -2.421 & $\mathrm{C}_{11} \mathrm{C}(\mathrm{OH}) \mathrm{C}_{2} \mathrm{SO}_{3} \mathrm{Na}$ & -2.199 & $\mathrm{C}_{12} \mathrm{hePhSO}_{3} \mathrm{Na}$ & -4.164 \\
\hline $\mathrm{C}_{14} \mathrm{SO}_{3} \mathrm{Na}$ & -2.602 & $\mathrm{C}_{11} \mathrm{C}\left(\mathrm{OC}_{2} \mathrm{OH}\right) \mathrm{C}_{2} \mathrm{SO}_{3} \mathrm{Na}$ & -3.445 & $\mathrm{C}_{14} \mathrm{PhePhSO}_{3} \mathrm{Na}$ & -4.759 \\
\hline $\mathrm{C}_{15} \mathrm{SO}_{3} \mathrm{Na}$ & -3.139 & $\mathrm{C}_{11} \mathrm{C}\left(\mathrm{EO}_{2}\right) \mathrm{C}_{2} \mathrm{SO}_{3} \mathrm{Na}$ & -2.922 & $\mathrm{C}_{12} \mathrm{AlaPhSO}_{3} \mathrm{Na}$ & -3.351 \\
\hline $\mathrm{C}_{16} \mathrm{SO}_{3} \mathrm{Na}$ & -3.131 & $\mathrm{C}_{11} \mathrm{C}(\mathrm{OPh}) \mathrm{C}_{2} \mathrm{SO}_{3} \mathrm{Na}$ & -3.641 & $\mathrm{C}_{11} \mathrm{C}$ (morpholino) $\mathrm{C}_{2} \mathrm{SO}_{3} \mathrm{Na}$ & -3.106 \\
\hline $\mathrm{C}_{17} \mathrm{SO}_{3} \mathrm{Na}$ & -3.635 & $\mathrm{C}_{11} \mathrm{C}\left(\mathrm{OPhC} \mathrm{PH}_{13}\right) \mathrm{C}_{2} \mathrm{SO}_{3} \mathrm{Na}$ & -4.787 & $\mathrm{C}_{11} \mathrm{C}$ (piperidino) $\mathrm{C}_{2} \mathrm{SO}_{3} \mathrm{Na}$ & -3.310 \\
\hline $\mathrm{C}_{10} \mathrm{C}=\mathrm{CSO}_{3} \mathrm{Na}$ & -1.886 & $\mathrm{C}_{11} \mathrm{C}\left(\mathrm{NC}_{2}\right) \mathrm{C}_{2} \mathrm{SO}_{3} \mathrm{Na}$ & -2.964 & & \\
\hline $\mathrm{C}_{12} \mathrm{C}=\mathrm{CSO}_{3} \mathrm{Na}$ & -2.569 & $\mathrm{C}_{11} \mathrm{C}\left(\mathrm{NC}_{3}\right) \mathrm{C}_{2} \mathrm{SO}_{3} \mathrm{Na}$ & -3.200 & & \\
\hline $\mathrm{C}_{14} \mathrm{C}=\mathrm{CSO}_{3} \mathrm{Na}$ & -3.215 & $\mathrm{C}_{11} \mathrm{C}\left(\mathrm{NC}_{4}\right) \mathrm{C}_{2} \mathrm{SO}_{3} \mathrm{Na}$ & -3.708 & & \\
\hline $\mathrm{C}_{16} \mathrm{C}=\mathrm{CSO}_{3} \mathrm{Na}$ & -3.745 & $\mathrm{C}_{11} \mathrm{C}(\mathrm{O}) \mathrm{C}_{2} \mathrm{SO}_{3} \mathrm{Na}$ & -2.174 & & \\
\hline $\mathrm{C}_{10} \mathrm{C}(\mathrm{C}) \mathrm{SO}_{3} \mathrm{Na}$ & -1.827 & $\mathrm{C}_{13} \mathrm{C}(\mathrm{OH}) \mathrm{C}_{2} \mathrm{SO}_{3} \mathrm{Na}$ & -2.839 & & \\
\hline $\mathrm{C}_{9} \mathrm{C}\left(\mathrm{C}_{2}\right) \mathrm{SO}_{3} \mathrm{Na}$ & -1.730 & $\mathrm{C}_{13} \mathrm{C}(\mathrm{OC}) \mathrm{C}_{2} \mathrm{SO}_{3} \mathrm{Na}$ & -3.472 & & \\
\hline $\mathrm{C}_{8} \mathrm{C}\left(\mathrm{C}_{3}\right) \mathrm{SO}_{3} \mathrm{Na}$ & -1.635 & $\mathrm{C}_{13} \mathrm{C}\left(\mathrm{OC}_{3}\right) \mathrm{C}_{2} \mathrm{SO}_{3} \mathrm{Na}$ & -4.089 & & \\
\hline $\mathrm{C}_{7} \mathrm{C}\left(\mathrm{C}_{4}\right) \mathrm{SO}_{3} \mathrm{Na}$ & -1.548 & $\mathrm{C}_{13} \mathrm{C}\left(\mathrm{OC}_{4}\right) \mathrm{C}_{2} \mathrm{SO}_{3} \mathrm{Na}$ & -4.458 & & \\
\hline $\mathrm{C}_{6} \mathrm{C}\left(\mathrm{C}_{5}\right) \mathrm{SO}_{3} \mathrm{Na}$ & -1.442 & $\mathrm{C}_{13} \mathrm{C}(\mathrm{O}) \mathrm{C}_{2} \mathrm{SO}_{3} \mathrm{Na}$ & -2.735 & & \\
\hline
\end{tabular}


Statistical Package for the Social Sciences (SPSS) ver 25.0 was used. All calculations and analysis was performed by 1 Personal Computer (PC). The specifications of this $P C$ are intel Core2Quad processor, $3 \mathrm{MB}$ of RAM, $500 \mathrm{~GB}$ of harddisk and windows 7 operating system, and also MS office.

\section{Procedure}

\section{Molecular Modeling of Surfactant}

Each compound is drawn into a three dimensional (3D) model of compound in the Hyperchem Release 8.0 molecular modeling program. Then, each model is saved into HIN file format (Hypercube, 2007).

\section{Generating Theoretical Predictors}

The predictors in this study are theoretical predictors that are generated by computational chemistry calculation. They consist of the physicochemical properties of sulfonate-based anionic surfactant. The predictors are used as independent variables in statistical analysis (Iswanto, 2011). They are assumed as an important factors on micelle forming and physical properties of surfactant. They are the charge of Carbon atom at polar and non-polar side of hydrocarbon chain of surfactant compound, dipole moment, partition coefficient (Log P), polarizability, refractive index, molecular weight, volume and surface area of van der Waals or QSAR properties calculations. The polar side Carbon atom $\left(C_{\text {polar }}\right)$ is the Carbon atom which binds the sulfonate functional group. The non polar side Carbon atom $\left(C_{\text {non polar }}\right)$ is the farthest Carbon atom from the $C_{\text {polar }}$ atom in the main hydrocarbon chain of sulfonatebased surfactant.

The charge of Carbon atom and dipole moment are obtained by Geometry Optimization calculation of surfactant structure. The other predictors or independent variables are obtained by QSAR properties calculations. All of the predictor calculations are calculated by Hyperchem Release 8.0. The calculation used semiempirical ZINDO/1 method, RHF spin pairing, the lowest state, PolakRibiere optimization algorithm and $0.001 \mathrm{kcal} . \AA$ '.mole-1 of RMS Gradient (Iswanto, 2011). Dependent variable or symbol with $\mathrm{P}$ in the Equation (1.1) in this study is the log of experimental Critical Micelle Concentration (Log CMC) of the sulfonatebased anionic surfactant.

\section{Constructing QSPR Equation}

Construction of QSPR equation is conducted by Multiple Linear Regression (MLR) statistical analysis based on backward method. All of the theoretical predictors are used as independent variables and the log CMC data are used as dependent variables. By looking to the quality of statistical parameters, the selected QSPR equation is chosen. The general form of QSPR equation is described by Equation 1.

$P=C+b_{1} \cdot x_{1}+b_{2} \cdot x_{2}+b_{3} \cdot x_{3}+\ldots \ldots .$. (1)

$$
\text { Where: } \begin{aligned}
P & =\text { compound's property } \\
C & =a \text { constant } \\
x_{n} & =n^{\text {th }} \text { variable }=n^{\text {th }} \text { predictor } \\
b_{n} & =a \text { coefficient of } n^{\text {th }} \text { predictor }
\end{aligned}
$$

\section{RESULTS AND DISCUSSION \\ Molecular Modeling}

Molecular modeling is important step for describing the chemical system in computational chemistry approach. The detailed checking of three dimensional structure of the sulfonate surfactant model is also important. If the structure is not correctly represented, the calculation of predictors would also give wrong results. Modeling chemical system is one of important things besides choosing calculation method in computational chemistry study (Iswanto, 2011). The result from modeling step is a three dimensional coordinate of the compound. This three dimensional coordinate is applied for calculation of theoretical predictor.

\section{Theoretical Predictors}

Geometry optimization of sulfonate-based surfactant structure was conducted to obtaining the theoretical predictors. The geometry optimization structure calculation used semiempirical ZINDO/1 method. The semiempirical ZINDO/1 method is the electronic structure calculation method that neglects the electron interaction integral. The calculation is not time consuming and electronic structure data can be easily obtained. The ZINDO/1 method is suitable for bulky structure of organic compound which consists of metal ion such as sulfonate-based surfactant. The semiempirical ZINDO/1 calculation method is already applied in corrosion inhibition of steel with some amino acids (Sikachina, 2018).

The theoretical predictors are the physicochemical properties which influence the value of Critical Micelle Concentration (Delsy, 2017). Results of theoretical predictors calculation show the theoretical characteristics of sulfonate-based anionic surfactant. The Carbon (C) atom net charges at polar and nonpolar side of main hydrocarbon chain and also dipole moment of surfactant describe the electronic properties, where as partition coefficient and molecular weight reflect the solubility and sterical properties of surfactant compounds, respectively. In the atomic net charges value, the various value is observed at the $\mathrm{C}_{\text {polar }}$ and $\mathrm{C}_{\text {non polar }}$. These significant differences in these $\mathrm{C}$ atom net charges are due to the difference in functional group or substituent which is binded at them.

If sulfonate functional group is binded by phenyl and also branched alkene, the $\mathrm{C}_{\text {polar }}$ will have positive net charge. In contrast, if sulfonate functional group is binded by linear alkene, the $\mathrm{C}_{\text {polar }}$ will have negative net charge. For instance, $\mathrm{C}_{\text {polar }}$ of $\mathrm{C}_{8} \mathrm{C}\left(\mathrm{C}_{3}\right) \mathrm{PhSO}_{3} \mathrm{Na}$ and $\mathrm{C}_{8} \mathrm{SO}_{3} \mathrm{Na}$ are 0.0778 and 0.060 coulomb, respectively. The $\mathrm{C}_{\text {polar }}$ of 
$\mathrm{C}_{8} \mathrm{C}\left(\mathrm{C}_{3}\right) \mathrm{PhSO}_{3} \mathrm{Na}$ has positive charge due to the attractive electron functional group of sulfonate. In the case of $\mathrm{C}_{8} \mathrm{SO}_{3} \mathrm{Na}$, the linear hydrocarbon could push the electron to the $\mathrm{C}_{\text {polar }}$ and the $\mathrm{C}_{\text {polar }}$ charge becomes negative (Iswanto, 2011). In the one sulfonate-based surfactant molecule the charge of $\mathrm{C}_{\text {polar }}$ is more positive than $\mathrm{C}_{\text {non polar }}$. This is occurred due to the attractive electron functional group of sulfonate at the $\mathrm{C}_{\text {polar }}$.

The dipole moment values are also different among the sulfonate-based surfactant. The highest value is observed in $\mathrm{C}_{8} \mathrm{PhePhSO}_{3} \mathrm{Na}$ compound. Its dipole moment value is $27.477 \mathrm{D}$. This surfactant has various electronegative atom in the molecular structure and large of size. The symbol Phe and $\mathrm{Ph}$ represent the Phenylalanine amino acid and Phenyl, respectively. The lowest dipole moment value is observed in $\mathrm{C}_{7} \mathrm{C}\left(\mathrm{C}_{6}\right) \mathrm{PhSO}_{3} \mathrm{Na}$ compound. The value is $3.381 \mathrm{D}$. This compound does not have various electronegative atom. Dipole moment value is influenced by the difference in electronegativity among the atoms and the geometry of certain functional group in the structure (Iswanto, 2011). Solubility property is described by the Log $P$ value. The highest dan the lowest Log $P$ value are found in $\mathrm{C}_{11} \mathrm{C}\left(\mathrm{OPhC}_{13}\right) \mathrm{C}_{2} \mathrm{SO}_{3} \mathrm{Na}$ and $\mathrm{C}_{6} \mathrm{CO}_{2} \mathrm{CSO}_{3} \mathrm{Na}$, respectively.

Based on molecular structure, the $\mathrm{C}_{6} \mathrm{CO}_{2} \mathrm{CSO}_{3} \mathrm{Na}$ compound is more polar and more soluble in water. Solubility property is influenced by the property of functional group in the compound. The sterical properties are observed by refractive index, molecular weight, volume and surface area of van der Waals. The surfactant which has various atom and large size of molecule, will have high value of sterical properties.

\section{The QSPR Equation Candidates}

The theoretical predictors which calculated by semiempirical ZINDO/1 calculation are applied for obtaining the QSPR equation. Statistical analysis is applied for obtaining this equation. Statistical analysis which is applied for obtaining QSPR equation is regression analysis. The dependent variables are 108 CMC exeperimental data. The independent variables are the theoretical predictors. The number of dependent and independent variables are enough to conducting the multiple linear regression (MLR) analysis. The $M L R$ is the simple regression analysis for multiple independent variable. In one step of statistical calculation, the QSPR equation will be obtained (Delsy, 2017).

Before MLR analysis conducted, the dependent variables are divided into 2 categories. The first category is fitting data which are used to obtaining the QSPR equation. The second category is the testing data which are used to selecting the best QSPR equation. Based on the random selection or used RAND function of Microsoft Excel calculation, the fitting data are 70 sulfonate surfactant compounds and the testing data are 38 compounds (Table 2).

Table 3 shows the important theoretical predictors in the six QSPR equation candidates. These candidates are obtained by Backward method of MLR statistical analysis. The six QSPR equation candidates have almost similar correlation coefficient $(r)$ value. Further step is needed for selecting the best QSPR equation. Selecting the best QSPR equation form the six candidates is conducted by the 38 sulfonate surfactants as testing data.

Table 2. Sulfonate surfactants that used to be testing data or testing compounds for QSPR equation selection

Testing compounds or testing data for QSPR equation

\begin{tabular}{|c|c|c|}
\hline $\mathrm{C}_{12} \mathrm{C}(\mathrm{C}) \mathrm{PhSO}_{3} \mathrm{Na}$ & $\mathrm{C}_{9} \mathrm{C}\left(\mathrm{OC}_{2}\right) \mathrm{C}_{2} \mathrm{SO}_{3} \mathrm{Na}$ & $\mathrm{C}_{8} \mathrm{C}\left(\mathrm{C}_{5}\right) \mathrm{PhSO}_{3} \mathrm{Na}$ \\
\hline $\mathrm{C}_{11} \mathrm{C}\left(\mathrm{OC}_{2} \mathrm{OH}\right) \mathrm{C}_{2} \mathrm{SO}_{3} \mathrm{Na}$ & $\mathrm{C}_{4} \mathrm{C}\left(\mathrm{C}_{2}\right) \mathrm{CCO}_{2} \mathrm{CC}\left(\mathrm{SO}_{3} \mathrm{Na}\right) \mathrm{CO}_{2} \mathrm{CC}\left(\mathrm{C}_{2}\right) \mathrm{C}_{4}$ & $\mathrm{C}_{9} \mathrm{C}\left(\mathrm{C}_{3}\right) \mathrm{PhSO}_{3} \mathrm{Na}$ \\
\hline $\mathrm{C}_{10} \mathrm{C}=\mathrm{CSO}_{3} \mathrm{Na}$ & $\mathrm{C}_{11} \mathrm{C}(\mathrm{C}) \mathrm{PhSO}_{3} \mathrm{Na}$ & $\mathrm{C}_{14} \mathrm{C}\left(\mathrm{CO}_{2} \mathrm{C}\right) \mathrm{SO}_{3} \mathrm{Na}$ \\
\hline $\mathrm{C}_{12} \mathrm{C}\left(\mathrm{CO}_{2} \mathrm{C}\right) \mathrm{SO}_{3} \mathrm{Na}$ & $\mathrm{C}_{9} \mathrm{C}\left(\mathrm{C}_{2}\right) \mathrm{PhSO}_{3} \mathrm{Na}$ & $\mathrm{C}_{14} \mathrm{PhePhSO}_{3} \mathrm{Na}$ \\
\hline $\mathrm{C}_{10} \mathrm{C}(\mathrm{C}) \mathrm{SO}_{3} \mathrm{Na}$ & $\mathrm{C}_{15} \mathrm{C}(\mathrm{OH}) \mathrm{C}_{2} \mathrm{SO}_{3} \mathrm{Na}$ & $\mathrm{C}_{13} \mathrm{C}(\mathrm{C}) \mathrm{PhSO}_{3} \mathrm{Na}$ \\
\hline $\mathrm{C}_{9} \mathrm{C}(\mathrm{OH}) \mathrm{C}_{2} \mathrm{SO}_{3} \mathrm{Na}$ & $\mathrm{C}_{13} \mathrm{C}(\mathrm{O}) \mathrm{C}_{2} \mathrm{SO}_{3} \mathrm{Na}$ & $\mathrm{C}_{7} \mathrm{C}\left(\mathrm{C}_{6}\right) \mathrm{PhSO}_{3} \mathrm{Na}$ \\
\hline $\mathrm{C}_{12} \mathrm{SO}_{3} \mathrm{Na}$ & $\mathrm{C}_{14} \mathrm{C}\left(\mathrm{CO}_{2} \mathrm{C}_{2}\right) \mathrm{SO}_{3} \mathrm{Na}$ & $\mathrm{C}_{11} \mathrm{C}\left(\mathrm{EO}_{2}\right) \mathrm{C}_{2} \mathrm{SO}_{3} \mathrm{Na}$ \\
\hline $\mathrm{C}_{6} \mathrm{C}\left(\mathrm{C}_{4}\right) \mathrm{PhSO}{ }_{3} \mathrm{Na}$ & $\mathrm{C}_{9} \mathrm{C}(\mathrm{OC}) \mathrm{C}_{2} \mathrm{SO}_{3} \mathrm{Na}$ & $\mathrm{C}_{13} \mathrm{C}(\mathrm{OC}) \mathrm{C}_{2} \mathrm{SO}_{3} \mathrm{Na}$ \\
\hline $\mathrm{C}_{13} \mathrm{C}(\mathrm{OH}) \mathrm{C}_{2} \mathrm{SO}_{3} \mathrm{Na}$ & $\mathrm{C}_{12} \mathrm{CO}_{2} \mathrm{C}_{2} \mathrm{SO}_{3} \mathrm{Na}$ & $\mathrm{C}_{12} \mathrm{C}(\mathrm{C}(\mathrm{OH})) \mathrm{SO}_{3} \mathrm{Na}$ \\
\hline $\begin{array}{l}\mathrm{C}_{7} \mathrm{C}\left(\mathrm{C}_{2}\right) \mathrm{PhSO}_{3} \mathrm{Na} \\
\mathrm{C}_{11} \mathrm{C}(\text { Morpholino }) \mathrm{C}_{2} \mathrm{SO}_{3} \mathrm{Na} \\
\mathrm{C}_{11} \mathrm{C}\left(\mathrm{OPhC} \mathrm{OP}_{13}\right) \mathrm{C}_{2} \mathrm{SO}_{3} \mathrm{Na} \\
\mathrm{C}_{9} \mathrm{C}(\mathrm{OPh}) \mathrm{C}_{2} \mathrm{SO}_{3} \mathrm{Na}\end{array}$ & $\begin{array}{l}\mathrm{C}_{11} \mathrm{C}\left(\mathrm{NC}_{3}\right) \mathrm{C}_{2} \mathrm{SO}_{3} \mathrm{Na} \\
\mathrm{C}_{11} \mathrm{C}(\mathrm{Piperidino}) \mathrm{C}_{2} \mathrm{SO}_{3} \mathrm{Na} \\
\mathrm{C}_{4} \mathrm{CO}_{2}\left(\mathrm{SO}_{3} \mathrm{Na}\right) \mathrm{CCO}_{2} \mathrm{C}_{4} \\
\mathrm{C}_{9} \mathrm{C}\left(\mathrm{C}_{4}\right) \mathrm{PhSO}_{3} \mathrm{Na}\end{array}$ & $\begin{array}{l}\mathrm{C}_{9} \mathrm{C}\left(\mathrm{C}_{2}\right) \mathrm{SO}_{3} \mathrm{Na} \\
\mathrm{C}_{11} \mathrm{C}(\mathrm{OPh}) \mathrm{C}_{2} \mathrm{SO}_{3} \mathrm{Na} \\
\mathrm{C}_{16} \mathrm{C}\left(\mathrm{CO}_{2} \mathrm{C}_{3}\right) \mathrm{SO}_{3} \mathrm{Na}\end{array}$ \\
\hline
\end{tabular}


Table 3. The important theoretical predictors or independent variable in the QSPR equation candidates based on statistical calculation of multiple linear regression Backward method. These candidates are obtained by fitting the 70 CMC experimental data of sulfonate-based surfactant compounds.

\begin{tabular}{|c|c|c|c|c|c|}
\hline $\begin{array}{l}\text { Model } \\
\text { or } \\
\text { Equation }\end{array}$ & Independent Variable & $r$ & $r^{2}$ & SE & $\mathrm{F}_{\mathrm{cal}} / \mathrm{F}_{\text {table }}$ \\
\hline 1 & $\begin{array}{l}q C_{1}, q C_{2}, R_{d}, \log P \text {, Polarizability, } \\
\text { dipole moment, } M W, A_{v d w}, V_{v d w}\end{array}$ & 0.965 & 0.931 & 0.259898 & 44.193954 \\
\hline 2 & $\begin{array}{l}q C_{1}, q_{2} \text {, Log } P \text {, Polarizability, } \\
\text { dipole moment, } M W, A_{v d w}, V_{v d w}\end{array}$ & 0.965 & 0.931 & 0.257764 & 25.771324 \\
\hline 3 & $\begin{array}{l}\mathrm{qC}_{1}, \mathrm{qC}_{2} \text {, Log } \mathrm{P}_{1} \text { Polarizability, } \\
\text { dipole moment, } \mathrm{MW}, \mathrm{V}_{\mathrm{vdw}}\end{array}$ & 0.965 & 0.931 & 0.256297 & 29.800466 \\
\hline 4 & $\begin{array}{l}\mathrm{qC}_{1}, q \mathrm{C}_{2} \text {, Log } \mathrm{P}, \mathrm{V}_{\mathrm{vdw}}, \mathrm{MW} \text {, dipole } \\
\text { moment }\end{array}$ & 0.964 & 0.930 & 0.255924 & 34.857340 \\
\hline 5 & $\mathrm{qC}_{1}, \mathrm{qC}_{2}, \log \mathrm{P}, \mathrm{V}_{\mathrm{vdw}}, \mathrm{MW}$ & 0.964 & 0.929 & 0.255685 & 41.889234 \\
\hline 6 & $q C_{1}, \log P, V_{v d w}, M W$ & 0.963 & 0.927 & 0.256314 & 52.054614 \\
\hline
\end{tabular}

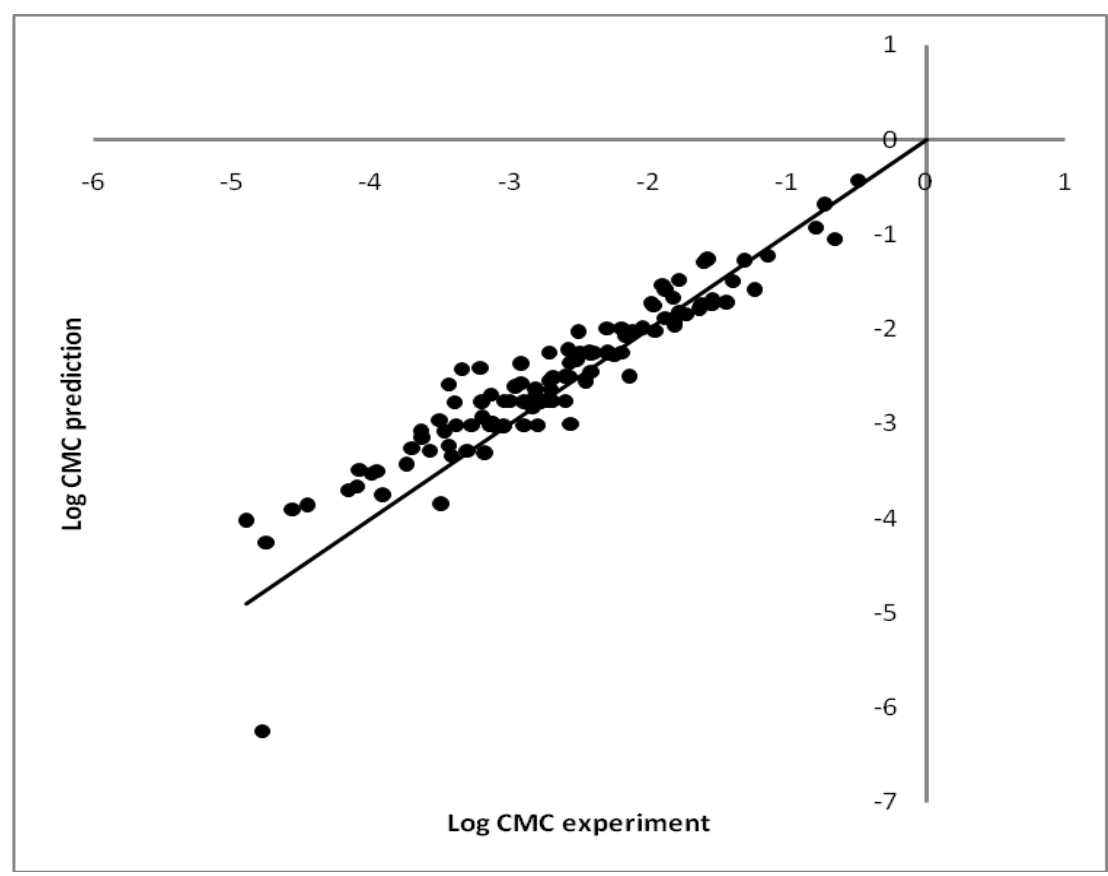

Figure 1. Plot the Log CMC prediction of sulfonate-based surfactants which are calculated by QSPR equation based on semiempirical ZINDO/1 against their Log CMC experiment (dot). The straight line represents if all of the Log CMC prediction values equal to Log CMC experiment.

\section{The Final QSPR equation}

Selection of the best QSPR equation is conducted with evaluation of the statistical parameters such as $r$ (correlation coefficient), $r^{2}$ (determination coefficient), $F$ (variance analysis), SE (standard error) and PRESS (Prediction Residual Sum of Squares) (Iswanto, 2011). Based on the evaluation process against the six QSPR equation candidates, the $6^{\text {th }}$ QSPR candidate is the best equation. It has good quality of statistical parameters (Table 2). It also has the smallest of PRESS value. It means that the $6^{\text {th }}$ QSPR candidate has the best quality for predicting the theoretical $C M C$ value of sulfonate-based surfactant.

The final QSPR equation is obtained by multiple linear regression enter method to the fitting and testing data or to the $108 \mathrm{CMC}$ of sulfonate-based surfactant. The final QSPR equation consists of 4 important theoretical predictors. There are the charge of $\mathrm{C}_{\text {polar }}\left(q \mathrm{C}_{1}\right)$, partition coefficient of $\mathrm{n}$-octanol/water (Log P), van der Waals volume (Vvdw) and molecular weight (MW). The final QSPR equation is:

$\log C M C=1.519-0.155 \log P+0.010 M W-$ $0.021 \mathrm{~V}_{\mathrm{vdw}}+2.336 \mathrm{qC} \mathrm{C}_{1}$

This final QSPR equation has some characteristics. They are the number of data $(n)=108, r=0.937, r^{2}$ $=0.878, S E=0.3236$, and $F_{\text {calc }} / F_{\text {table }}=75.862$ and PRESS $=10.9394$.

The final QSPR equation has good correlation ( $r$ value) between Log CMC value and the 4 theoretical predictors or independent variable. This QSPR 
equation could explain over $87.8 \%$ variation of data (see $r^{2}$ value). Small error is also showed in this final QSPR equation (see SE value). This final QSPR equation is also accepted at $95 \%$ confidence level because its $F_{\text {calc }} / F_{\text {table }}$ is more than 1.00 (Iswanto, 2011). Based on the final QSPR equation, the most important theoretical predictor is the charge of $\mathrm{C}_{\text {polar }}$. This theoretical predictor has the highest value of coefficient. The capability of the QSPR equation in order to predict the CMC value is good. Most of the CMC prediction value is close to the $C M C$ experiment (Figure 1).

\section{CONCLUSIONS}

Computational chemistry calculation based on semiempirical ZINDO/1 method is good compromising between the accuracy and the capability of computer. The QSPR equation could be obtained by conducting the QSPR analysis against the CMC experimental value of sulfonate-based surfactants. The most important theoretical predictor could be shown in the highest coefficient value of its in the QSPR equation.

\section{ACKNOWLEDGMENTS}

PI acknowledges financial support from The Ministry of Education and Culture, Republic of Indonesia by Higher Education Competitive Research Grant Scheme. The contract number of PI research project is 1610/UN23.14/PN/2015.

\section{REFERENCES}

Chou, J. (2017). IBM SPSS 25 for Windows. Zendesk. Retrieved from http://www.paloaltou.zendesk.com

Delsy, E. V. Y., Iswanto, P., Winaryo, S. (2017). Analisis hubungan kuantitatif stuktur dan nilai konsentrasi misel kritik surfaktan anionik dengan metode semiempiris AM1. Molekul. 12(1): 53-60.
Elidrissi, B., Ousaa, A., Ghamali, M., Chtita, s., Ajana, M. A., Bouachrine M., and Lakhlifi, T. (2017). QSPR and DFT studies on the melting point of carbocyclic nitroaromatic compounds. J. Phys Chem Biophys. 7(2):245.

Haftka, J. J., Scherpenisse, P., Oetter, G., Hodges, G., Eadsforth, C. V., Kotthoff, M., Hermens, J. L. (2016). Critical micelle concentration values for Different surfactants measured with solidphase microextraction fibers. Environmental Toxicologi Chemistry. 35(9):2173-2181.

Huibers, P. D. T. (1999). Quantum-Chemical Calculatios of the Charge Distribution in Ionic Surfactans. Langmuir. 15. 7546-7550.

Hypercubelnc. (2007). Hyperchem Release 8.0 for Windows, Florida, USA.

Iswanto, P. M. Chasani. E. V. Y. Delsy. Harjono. I. Tahir dan M. Hanafi. (2011). Novel Design of Calanone Derivatives as Anti-Leukemia Compounds based on Quantitative StructureActivity Relationship Analysis. Indo. J. Chem. $11(1): 31-36$.

Paulo, A. M. S., Aydin, R., Dimitrov, M. R., Vreeling, H., Cavaleiro, A. J., García-Encina, P. A., Stams, A. J. M., Plugge, C. M. (2017). Sodium lauryl ether sulfate (SLES) degradation by nitrate-reducing bacteria. Appl. Microbiol. Biotechnol. 101(12):5163-5173

Sikachina, A., Beloglazov, S. (2018). QuantumChemical substantiation of corrosion inhibition of with some amino acids. Bulletin of Science and Practice. T. 4. No. 1. 2018r.

Zhu, Q., Huang, L., Su, J., Liu, S. (2014). A sensitive and visible fluorescence-turn-on probe for the CMC determination of ionic surfactants. Chem. Commun (Camb). 50(9):1107-1109. 